\title{
Towards an improved understanding of participation in natural hazard early warning systems
}

Georgina Clegg, Richard Haigh and Dilanthi Amaratunga

Global Disaster Resilience Centre, School of Applied Sciences, University of Huddersfield, Queensgate, Huddersfield, HD1 3DH, United Kingdom

\section{Abstract \\ Purpose}

This paper seeks to improve the conceptual understanding of the process of participation in early warning systems (EWS) through a review of participatory EWS examples in the academic literature. Specifically, the paper asks: who is involved, what responsibilities do participants hold, what activities are they involved in, and what are the associated successes, issues and outcomes?

\section{Design/methodology/approach}

Thirty cases of participation in EWS documented in the academic literature were identified through online searches. Existing concepts in participation (power and responsibility, communication) and people-centred early warning (risk knowledge, monitoring and warning, communication and dissemination and response capability) were used to examine each paper.

\section{Findings}

Participation was found to take place through a range of activities across all elements of the EWS. Participation also varied in breadth of inclusion, ranging from the general public to selected volunteers. The majority of cases received support and facilitation from other actors, such as government and NGOs, but the extent of power and responsibility held by participants varied greatly within this. Common successes and issues associated with participatory EWS and the potential outcomes are presented, and the opportunities, challenges and gaps in knowledge are discussed.

\section{Originality}

This paper links participation and EWS literature to form a clearer conceptualisation of participation in EWS in support of future research in the field. It provides unique insights into who participates, their roles and relations with other actors, and the outcomes of participation.

Keywords Community-based early warning system; EWS; community participation; disaster risk reduction; literature review; community engagement.

\section{Introduction}

Providing a warning to those at-risk prior to the onset of a natural hazard is a key method of reducing disaster risk. To achieve this, early warning systems (EWS) are used, defined as "integrated system[s] of hazard monitoring, forecasting and prediction, disaster risk assessment and preparedness activities" (UNDRR, 2020). Through the provision of an advanced alert, EWS allow people to move away from harm, thus reducing disaster risk. 
Although the effectiveness of EWS has increased significantly over time, particularly in the monitoring of conditions, due to advancements in technology (Hallegatte, 2012; Perera et al., 2019), issues with communication and response still prevail. Successfully communicating and disseminating a warning to all those at risk, and then generating an effective response within the population are frequently cited issues (Basher, 2006; United Nations, 2006; Garcia and Fearnley, 2012; Baudoin et al., 2016; Perera et al., 2020). These predominantly social issues have not been addressed by the technology-led, 'hazard-centred' systems that have been developed (Perera et al., 2020).

The need for 'people-centred' EWS, focused on empowering people to act, is now widely acknowledged. The notion emerged as a result of the International Conference on Early Warning in 2006 (UNISDR, 2006). Findings of the conference state that "people-centred early warning systems rely on the direct participation of those most likely to be exposed to hazards" (UNISDR, 2006). A participatory focus is thus a key part of the approach. Since 2006, there has been a growing number of publications detailing attempts to implement a participatory, people-centred approach. However, the literature is difficult to navigate for several reasons. Participation itself is complex and has been understood in different ways. This has led to various interpretations of how people can, or should, participate. In addition, there are various terminologies associated with participation in EWS (Marchezini et al., 2018), and current knowledge exists as fragmented case studies.

This article seeks to understand the nature of participation in EWS through examining examples of participatory EWS documented in the academic literature. The study draws on existing concepts in participation, such as participant power and responsibility and mode of communication, and the four elements of effective early warning (risk knowledge, monitoring and warning, communication and dissemination, and response capability) (United Nations, 2006) to provide a more coherent conceptualisation of the process.

Firstly, a literature review drawing out the key aspects of participation and people-centred EWS is presented. The methodology used to conduct the review is then described. This is followed by the findings of the review, arranged around four key questions: Who participates? What activities are they involved in? Who are the other actors involved and what are their roles? And, what are the common successes, issues and outcomes? A summary and discussion of the opportunities, challenges and knowledge gaps is given, followed by conclusions and recommendations for future research.

\section{Participatory people-centred early warning systems}

\subsection{People-centred EWS}

People-centred EWS are considered to have four elements: risk knowledge, monitoring and warning, communication and dissemination and response capability (UNISDR, 2006; United Nations, 2006). The risk knowledge element regards the production of knowledge on risk, which may include, for example, risk assessments. Monitoring and warning concerns the monitoring of hazard variables, and the generation of warnings. Dissemination and communication regard the communication of warnings and risk information in a clear and useable fashion to all those at risk. Response capability is about ensuring those at-risk 
understand the risks, and that they know what to do when a warning is received. This may include education programmes to raise awareness and response plans (UNISDR, 2006).

Participation is an important 'cross-cutting' aspect of people-centred EWS (United Nations, 2006). There is, however, no single understanding of what participation in EWS consists of. The literature applies a range of terminologies which makes the concept difficult to grasp. This was highlighted by Marchezini et al. (2018) who identify the use of 'people-centred' along with 'community EWS' (IFRC, 2012), 'community-based EWS' (Marcherera and Chimbari, 2016), 'community-centric EWS' (Baudoin et al., 2016), 'last-mile' (Basher, 2006; Kelman and Glantz, 2014) and 'participatory' (Marchezini et al., 2017). Others could also be added, such as 'unofficial' EWS (Parker and Handmer, 1998). These terms generally all involve participation, but this can have different forms. For example, Baudoin et al. (2016) suggest community-centric EWS are where people at-risk initiate and control the whole system. While terms like community-based can refer to where the community are partners in the system (IFRC, 2012).

\subsection{Participation}

Participation originally referred to the involvement of citizens in government decision making (Baum, 2001). However, the term has come to mean "almost anything that involves people" (Cornwall, 2008). A study by Fekete et al. (2021) identified that understandings of the term 'participation' vary, even amongst those working in the disaster management field within the same country. To avoid confusion with different terminologies above, this paper uses the term participation broadly to refer to the involvement of people at-risk in EWS, and to encompass the various manifestations.

The process of participation has been understood in various ways. One of the most common conceptualisations is Arnstein's Ladder (1969). The Ladder represents different levels of citizen power from 'non-participation' (where citizens are merely provided with information), to 'citizen control' (were citizens are the primary decision makers). It assumes that greater citizen power is preferable to other types. However, the Ladder has been criticised in this respect, in that greater citizen power is not always more effective (Fung, 2006; Cornwall, 2008; Reed et al., 2018).

Alternatively, Rowe and Frewer (2005) view participation in terms of communication between participants and 'sponsors' (facilitators). Public participation is understood as a two-way information exchange, with dialogue between participants and sponsors. They distinguish this from public communication and consultation, which feature one-way flows of information only.

Fung (2006) combines power and communication with 'breadth' of participation (who is involved in the process) in his three-dimensional view of participation. Each dimension is a scale, allowing for different combinations to be realised. A similar framework, the 'wheel' of participation (proposed by Davidson (1998), and recently elaborated by Reed et al. (2018)), also concerns the level of communication (from one-way communication to two-way coproduction) as well as agency, or who leads the process (spanning top-down to bottom-up forms). The framework also allows for different combinations of the two. 
Although there is no single way of understanding participation, these highly cited frameworks reveal several key facets: 1 . The degree of power and responsibility held by participants; 2 . The mode of communication taking place between participants and other actors; 3. Who is participating in the process. Cornwall (2008) notes that it is also necessary to understand what activities are being participated in (4.). While these key facets indicate what is taking place, they do not suggest whether the process is effective. The 'effectiveness' of participation can be interpreted in different ways, however, there are two main approaches. The first is that there may be features of the process that enable success, and the second is that effective final outcomes are delivered (Rower and Frewer, 2000). Both process and outcomes are considered in this paper.

\subsection{Previous studies}

Baudoin et al. (2016) describes three modes of participation in EWS - a 'top-down' approach, which is predominantly led by authorities, a 'community-centric' method, where the community take the lead, and a 'hybrid' model, that combines elements of both. However, there is currently a lack of information on who is participating, their interaction with other actors, and what activities people are participating in.

Previous studies have reviewed the literature on participation in EWS. Marcherera and Chimbari (2016) review 'community-based' EWS with a view to designing a system for Malaria. Marchezini et al. (2018) review participatory EWS, this time with the objective of identifying links with citizen science initiatives. Sufri et al. (2020) review community engagement in disaster EWS and identify the elements communities commonly participate in and associated activities. These studies generally focus on the process of participation, rather than the outcomes. This study builds upon previous reviews by linking EWS more directly to participation literature with the aim of providing a more holistic understanding of participatory EWS, including the types of participants, and other actors. It also reviews the potential successes, issues and outcomes of the process.

\section{Methodology}

A review of participatory EWS described in the existing literature was conducted. Drawing on the conceptualisations of participation as frames of reference, the study aimed to answer the following questions:

Who participates in natural hazard EWS?

What activities are participants involved in?

What level of responsibility and power do participants have?

What modes of communication take place?

What are the successes, issues and outcomes of participation in EWS?

Participatory activities were identified using the four elements of effective EWS according to the criteria in Table I. The four elements have also been used to assess EWS by Sufri et al. (2020). While who participates in what activities was straightforward to identify, levels of responsibility and communication were more complex. Therefore, this was explored through examining the roles of other actors involved, and how they relate to participants i.e. Who are the other actors involved and what is their role in relation to other participants? 
Ta ble I: Crite ria used for s election of participatory a ctivi ties associated with each of the four elements of effective early warning. Based on UNISDR (2006).

\begin{tabular}{|l|l|}
\hline \multicolumn{1}{|c|}{ Element of effective early warning } & \multicolumn{1}{c|}{ Criteria } \\
\hline Risk knowledge & $\begin{array}{l}\text { Any activity that helps citizens understand risk, } \\
\text { through the generation or sharing of knowledge. }\end{array}$ \\
\hline Monitoring/warning & $\begin{array}{l}\text { Any activity that engages participants in the } \\
\text { monitoring of the hazard or in generating a warning. }\end{array}$ \\
\hline Communication/dissemination & $\begin{array}{l}\text { Any activity through which participants } \\
\text { communicate risk information, or by which they } \\
\text { contribute to the dissemination of warnings to the } \\
\text { community or other actors. }\end{array}$ \\
\hline Response capability & $\begin{array}{l}\text { Any participation that contributes to improving } \\
\text { response capability. This may include e.g. drills but } \\
\text { also activities that raise awareness (education } \\
\text { programmes etc.). }\end{array}$ \\
\hline
\end{tabular}

Relevant academic literature (books, journal articles, peer-reviewed conference papers) were identified through online searches using Google Scholar and the University of Huddersfield's online library portal. The following search terms were used: 'alert'; 'community'; 'community-based'; 'engagement'; 'early warning system'; 'participation'. The inclusion criteria were: the paper should be related to EWS for natural hazards; it should present an EWS with participation as an aspect, or recommendations for how people can participate more effectively; it should concern the active participation of people (not purely consultative forms). Thirty papers were identified in total.

The following information was extracted from each paper: Location of study; hazard(s) addressed; participants and other actors involved; activities via which people participate, and any stated successes, issues and outcomes.

\subsection{Overview of selected papers}

Selected papers included cases of participatory EWS from Africa, Asia, Europe, Oceania and South America. The majority of studies were from Asia (18/30), and flooding was the most common hazard (16/30) with multiple hazards (e.g. flood and landslide) and landslides also common. Other examples included volcanic and fire hazards. These findings are in line with previous studies which also found flooding and Asia as the dominant hazard and location in the existing literature (Marchezini et al., 2018; Sufri et al., 2020).

\section{Findings}

\subsection{Who participates?}

When identifying who was participating in each case, five dominant types emerged: 1 . General public, 2. At-risk community, 3. Specific demographic group, 4. Community organisation (or network; committee), and 5. Selected volunteers. General public refers to where any citizen may participate. Examples of this type included where participation was via an online application (Lanfranchi et al., 2014; Pineda, 2015; Henriksen et al., 2018). Others targeted a specific at-risk community (us ually defined geographically) or demographic group (e.g. school students (Marchezini et al., 2017) or women (Coles and Quintero-Angel, 2018)). A community organisation is where a group of participants come 
together in an organised fashion, often in the form of a community disaster group, or similar. 'Selected volunteers' indicates where there may be a selected individual, or network of volunteers, often responsible for a specific task. In some cases, more than one type of participant was engaged in a single initiative. For example, an at-risk community may be involved in risk knowledge activities, while a volunteer or community organisation is tasked with communication and dissemination responsibilities (Gautam and Phaiju, 2013; Thapa and Adhikari, 2019). The most common types were volunteers, at-risk community and community organisation. A full summary of findings is presented in Table II.

\subsection{What activities are participants involved in?}

\subsubsection{Risk knowledge}

Participants were engaged in the development and sharing of risk knowledge. This was commonly through participatory risk and vulnerability assessment. Other activities included forums for discussion and knowledge sharing, either between community participants and other supporting actors (e.g. (Paripurno and Nugroho, 2018)), or between the community themselves (Valdivia et al., 2010), such as workshops. To provide an example, Marchezini et al. (2017) detail a range of activities designed to build risk knowledge among high school students in Brazil. This included the students conducting risk mapping activities, as well as intergenerational dialogues, which enabled students to learn from more senior members of the community.

\subsubsection{Monitoring and warning}

In some cases participants were involved in the design of the monitoring and warning system alongside other actors (Fathani and Legono, 2012; Khan et al., 2018). Alternatively, participants had a more active role in carrying out monitoring themselves. For example, Abon et al. (2012) describe how volunteers monitored rainfall using rain gauges. In some cases, participants monitored and also produced the warning (Junnaedhi et al., 2017; Smith et al., 2017), where in others an authority played a role. For example, Espinueva and Nilo (2011) detail how volunteers made observations that were communicated to an operations centre, who subsequently determined whether a warning was issued. Other examples include less direct monitoring, such as submitting reports to authorities online for real-time monitoring purposes (Lanfranchi et al., 2014; Pineda, 2015; Henriksen et al., 2018).

\subsubsection{Communication and dissemination}

Communication and dissemination activities included the direct dissemination of warnings to other community members via voice, radio (Hori and Shaw, 2012; Paripurno and Nugroho, 2018), or mobile SMS (Junnaedhi et al., 2017; Smith et al., 2017). This tends to be the case when participants are also involved in monitoring activities. Alternatively, participants may receive warnings from authorities and then disseminate them further (Sari and Prayoga, 2018). Other examples included participants communicating information to authorities, who disseminate the warning, or confirm it before participants disseminate it (Espinueva and Nilo, 2011; Fathani and Legono, 2012; da Cunha Luz Barcellos et al., 2017).

\subsubsection{Response capability}

Participation associated with response capability included involvement in evacuation and contingency planning (Smith et al., 2017), simulations and drills, and education and 
awareness programmes (Gautam and Phaiju, 2013; Liu et al., 2016). Hori and Shaw (2012) document a suite of activities designed to build response capability conducted by the national risk prevention and emergency management commission in Costa Rica. This included workshops to build community awareness, development of a community contingency plan, and drills for self-organised evacuation.

\subsection{Who are the other actors involved and what are their roles?}

To understand more about participant responsibility and power, the involvement and roles of other actors were explored. In the majority of cases, participation was initiated or supported by actor(s) external to the participants. Participants were rarely solely responsible for the EWS. The other actors included: the government (Mulyasari and Shaw, 2013; Arias et al., 2016; Ghazali et al., 2018) or specific government department, such as a disaster agency or similar (Hori and Shaw, 2012; da Cunha Luz Barcellos et al., 2017); meteorological office (Espinueva and Nilo, 2011; Henriksen et al., 2018), NGOs (Smith et al., 2017; Sari and Prayoga, 2018) and research bodies or universities (Valdivia et al., 2010; Abon et al., 2012; Marchezini et al., 2017; Thapa and Adhikari, 2019). These actors were often responsible for initiating the participatory EWS, such as by providing equipment and recruiting volunteers. Other common activities included facilitating workshops, or discussions, and providing training (Espinueva and Nilo, 2011; Hori and Shaw, 2012; da Cunha Luz Barcellos et al., 2017).

Greater participant responsibility and power was shown by a community disaster risk management organisation in Thailand, described by Tanwattana (2018). The organisation was established bottom-up by the community and the members developed their own river gauges, and conducted monitoring. These activities were supported via a community fund. Later, the organisation began to collaborate with a local university who helped them to advance their flood risk mapping activities.

[Table II here]

\subsection{What are the successes, issues and outcomes?}

\subsubsection{Common successes and issues}

Successful aspects identified by the review often related to relationships between actors. For example, trust between actors was indicated as important (Betts, 2003; Espinueva and Nilo, 2011; Ghazali et al., 2018). In addition, the presence of key points of contact, such as a community group, were seen as beneficial. Such actors provided a trusted interface between the community and other actors, and supported coordination (Fathani and Legono, 2012; da Cunha Luz Barcellos et al., 2017; Sari and Prayoga, 2018). Tanwattana (2018) note how key actors (such as community leaders or groups of motivated community members) were also important for driving forward a community-led initiative. Furthermore, a clear outline of actors roles and communication protocols were also indicated to support the process (Stone et al., 2014; Sari and Prayoga, 2018).

A commonly identified issue was the sustainability of participation over time (Baudoin et al., 2016; Liu et al., 2016; Sari and Prayoga, 2018). For example, Liu et al. (2016) identify that migration, an aging population and limited social capacity undermined the 
sustainability of a participatory EWS in China. A loss of key contact persons can also contribute to problems maintaining the system (Stone et al., 2014; Baudoin et al., 2016). Several papers do, however, indicate what has supported, or may help sustainability of the system. Agreements, memorandums (Espinueva and Nilo, 2011; Arias et al., 2016) and policy instruments (Coles and Quintero-Angel, 2018) to institutionalise the participatory EWS is one suggested method. Other suggested activities revolve around ways to bring participants together and support networking, such as the establishment of a committee (Betts, 2003), knowledge sharing events and the use of social media (Baudoin et al., 2016). Such activities do not necessarily have to be EWS related, but can help to support networks nonetheless. Paripurno and Nugroho (2018), for example, identify activities such as breaking fast together as supporting networks between community groups in the Indonesian context.

Other identified issues surround the suitability of participatory monitoring. Abon et al. (2012) note that volunteer observers were concerned that time-consuming monitoring activities may interfere with their daily lives. Further, Smith et al. (2017) note that manual monitoring may not be possible, or may be dangerous under severe conditions or during the night, for example. This suggests participation monitoring may not always be suitable.

\subsubsection{Outcomes}

One method used to assess the outcomes within the reviewed studies is to judge the performance of the EWS as a whole during an event. For example, whether the system operated as planned, whether it allowed people to evacuate, or the number of fatalities compared to previous events (Espinueva and Nilo, 2011; Abon et al., 2012; Gautam and Phaiju, 2013; Baudoin et al., 2016; Paripurno and Nugroho, 2018; Thapa and Adhikari, 2019). Others identify specific outcomes of participation including the extension of monitoring networks (Gautam and Phaiju, 2013; Stone et al., 2014; Henriksen et al., 2018) improved understanding and awareness of the risk/hazard (Abon et al., 2012; Hori and Shaw, 2012; Baudoin et al., 2016; Liu et al., 2016), and increased preparedness among participants (Hori and Shaw, 2012; Gautam and Phaiju, 2013; Stone et al., 2014; da Cunha Luz Barcellos et al., 2017). While outcomes such as extended monitoring can be straightforwardly linked to participants taking observations in those cases, other outcomes, such as awareness and preparedness cannot be as clearly linked. It should be noted that the studies do not always indicate how these outcomes were assessed. Betts (2003) and Coles and Quintero-Angel (2018) both point out the difficulties of quantifying the impact of participation in EWS.

Stone et al. (2014) provide a more in-depth discussion on outcomes of an initiative in Ecuador. They identify that involvement in a monitoring network led to more timely evacuation and engagement with risk information. They suggest that this was owing to trust development between the participants and the scientists involved, thus confidence in the system. Other studies also note improved relationships resulting from participation (Espinueva and Nilo, 2011; da Cunha Luz Barcellos et al., 2017). Further, Stone et al., (2014) suggest that participation contributes to wider goals, such as involvement of the wider community in risk reduction planning and preparedness, beyond the immediate participants. Similarly, Hori and Shaw (2012) review an initiative in Costa Rica after ten years and identify outcomes that go beyond the EWS. They identify that one participant gained 
awareness of climate change from conducting monitoring activities. Both papers report on the perspectives of those involved in the EWS to identify outcomes.

\section{Discussion}

The literature review revealed that 'who participates' varies in terms of the scope of participants engaged. Of the examples reviewed, this ranged from systems where the general public can participate to those where only specific volunteers are involved. These types reflect different 'breadths' (Fung, 2006) of involvement. Generally, in cases where the general public are involved, participation is more ad-hoc, such as reporting of incidents to authorities when they occur, whereas in cases where a specific organisation or volunteers are involved, there tends to be more formalised participation and greater responsibility. Volunteers, at-risk community and community organisation were found to be the most common types. The prominence of EWS involving community organisations and volunteers raises questions about whether involvement of all those at risk is necessary, and whether/how narrower breadths of participation may support the wider community.

The review also identified that there are multiple participatory activities across the four elements of EWS. However, examples of participation in all four elements within a single case are limited to a few examples (Gautam and Phaiju, 2013; Smith et al., 2017). On the other hand, there may be multiple activities targeting a single element present in one case. It should be noted that although activities have been divided into the four elements of EWS for analysis purposes, a single activity may contribute to more than one element. For example, participants may report observations to authorities. In this way, a contribution is made to monitoring, but this may also contribute to the strengthening of pathways for communication and dissemination of risk information (Lanfranchi et al., 2014). In addition, participatory activities in risk knowledge, monitoring and warning and diss emination and communication, all have the potential to raise awareness, therefore increase the likelihood of response.

In relation to participant responsibility and power, Baudoin et al. (2016) identified three modes of participation in EWS: 'top-down', 'hybrid', and 'community-centric'. The review shed additional light onto this aspect. The majority of cases reviewed involved other actors, however, there were many different configurations of responsibility sharing across the cases. Some participants were less active, engaged in the design of the system and risk knowledge activities, while the system was largely operated by other actors (Betts, 2003; Thapa and Adhikari, 2019). These represent more 'top-down' approaches. Other participants were more active in the operation of the system and had greater responsibility (Abon et al., 2012; Smith et al., 2017). The various relations between participants and other actors are also evident in the various forms of communication. Some cases demonstrated strong 'two-way' communication, where participants interfaced between authorities and the community. However, some were more 'one-way'. For example, Coles and QuinteroAngel (2018) note how although participants were communicating information to authorities, they did not have an opportunity to apply their own local knowledge, and therefore were actually engaged in a more 'one-way' interaction. While relations between participants and authorities showed great diversity, they were highlighted as a successful aspect of several cases, indicating the potential importance of these links. These findings raise questions about how the different configurations of responsibility sharing and communication impact on the participation process and outcomes, and how effective 
communication links can be used to support participation and early warning. It should be noted that the dominance of other actors in these findings may be a result of the methods employed. The review included academic sources, but more bottom-up forms of participation may not be well recorded within these documents. This is a potential limitation of the study.

\section{Conclusions}

Examples of participatory EWS from the academic literature were reviewed with the purpose of clarifying the process of participation in natural hazard EWS. The review provided unique insights into the types of participants, which ranges in breadth from the general public to selected volunteers. Participants were involved in a variety of activities across the four elements of EWS, and hold various roles and responsibilities in relation to other actors. This provides a clearer understanding of the options available when implementing participation in EWS, as well as provides a conceptual basis for future research. The variety of participation in EWS observed raises questions for further investigation. It remains unclear what the best format or configuration for participation should be to deliver the best outcomes. Are all designs equally effective? What impacts might variations in who participates, and their roles and responsibilities in relation to other actors have on the outcomes obtained?

Successes, issues and outcomes were also reviewed. Relationships between the actors involved were suggested to support the participation process, while sustaining the system over time, and practicalities of involvement were identified as potential issues. Identified outcomes included specific factors, contribution to overall EWS performance, as well as potential impacts beyond the system. However, details on these remain limited and further questions are raised surrounding the outcomes of participation, and the links between activities and outcomes. What range of outcomes can be expected from participation in EWS? And can participation be tailored and targeted to achieve certain goals? While literature on participation in EWS is relatively new, insights may be gained from works in other related areas, such as disaster risk reduction or environmental management. Exploring these aspects should be the focus of future research.

\section{Acknowledgements}

This work was supported by the Natural Environment Research Council (Grant number: $\mathrm{NE} / \mathrm{S003282/1);} \mathrm{the} \mathrm{Economic} \mathrm{\&} \mathrm{Social} \mathrm{Research} \mathrm{Council;} \mathrm{Newton} \mathrm{Fund} \mathrm{and} \mathrm{Ministry} \mathrm{of}$ Research and Technology / National Agency for Research and Innovation (RISTEK-BRIN). The work was conducted as part of Georgina Clegg's doctoral programme, supervised by Richard Haigh and Dilanthi Amaratunga. An earlier version of this paper was presented at the 9th International Conference on Building Resilience (ICBR), Nusa Dua, Bali, $13-15^{\text {th }}$ January 2020.

\section{References}

Abon, C. C., David, C. P. C. \& Tabios, G. Q. (2012) “Community-based monitoring for flood early warning system: an example in central Bicol River Basin". Disaster Prevention and Management. 21 (1) pp.85-96. 
Arias, P. A., Villegas, J. C., Machado, J., Serna, A. M., Vidal, L. M., Vieira, C., Cadavid, C. A., Vieira, S. C., Angel, J. E. \& Mejia, O. A. (2016) "Reducing social vulnerability to environmental change: building trust through social collaboration on environmental monitoring". Weather, Climate and Society. 8, pp.57-66.

Arnstein, S. R. (1969) "A Ladder of Citizen Participation". Journal of the American Institute of Planners. 34 (4) pp.216-224.

Basher, R. (2006) “Global Early Warning Systems for Natural Hazards: Systematic and People Centred". Philosophical Transactions of The Royal Society A. 364, pp.2167-2182.

Baudoin, M.-A., Henly-Shepard, S., Fernando, N., Sitati, A. \& Zommers, Z. (2016) “From TopDown to "Community-Centric" Approaches to Early Warning Systems: exploring pathways to improve disaster risk reduction through community participation". International Journal of Disaster Risk Science 7 (2) pp.163-174.

Baum, H. S. (2001) Citizen Participation. In: Smelser, N. J. \& Baltes, P. B. (Eds.) International Encyclopedia of the Social \& Behavioral Sciences. Elsevier.

Betts, R. (2003) "The Missing Links in Community Warning Systems: findings from two Victorian community warning system projects". The Australian Journal of Emergency Management. 18 (3) pp.37-45.

Coles, A. R. \& Quintero-Angel, M. (2018) "From silence to resilience: prospects and limitations for incorporating non-expert knowledge into hazard management". Environmental Hazards. 17 (2) pp.128-145.

Cornwall, A. (2008) "Unpacking 'Participation': models, meanings and practices". Community Development Journal. 43 (3) pp.269-283.

da Cunha Luz Barcellos, P., Silva da Costa, M., Cataldi, M. \& Pereira Soares, C. A. (2017) "Management of non-structural measures in the prevention of flash floods: a case study in the city of Duque de Caxias, state of Rio de Janeiro, Brazil". Natural Hazards. 89 (1) pp.313-330.

Davidson, S. (1998) "Spinning the Wheel of Empowerment". Planning. (April 1998) pp.14-15. Espinueva, S. R. \& Nilo, P. D. (2011) Lessons Learned from Community-Based Early Warning System in the Philippines. In: Osti, R. \& Miyake, K. (Eds.) Forms of Community Participation in Disaster Risk Management Practices. New York: Nova Science Publishers.

Fathani, T. F. \& Legono, D. (2012) The Application of Monitoring and Early Warning System of Rainfall-Triggered Debris Flow at Merapi Volcano, Central Java, Indonesia. The 10th International Symposium on Mitigation of Geo-disasters in Asia. Kyoto, Japan: Kyoto University.

Fekete, A., Aslam, A.B., de Brito, M.M., Dominguez, I., Fernando, N., Illing, C.J., KC, A.K., Mahdavian, F., Norf, C., Platt, S., Santi, P.A. \& Tempels, B. (2021) "Increasing Flood Risk Awareness and Warning Readiness by Participation - but who understands what under 'participation'?". International Journal of Disaster Risk Reduction. 57 (2021) 102157.

Fung, A. (2006) "Varieties of Participation in Complex Governance". Public Administration Review. (December 2006) pp.66-75.

Garcia, C. \& Fearnley, C. J. (2012) "Evaluating Critical Links in Early Warning Systems for Natural Hazards". Environmental Hazards. 11, pp.123-137.

Gautam, D. R. \& Phaiju, A. G. (2013) "Community Based Approach to Flood Early Warning in West Rapti River Basin of Nepal". Journal of Integrated Disaster Risk Management. 3 (1) pp.155-169. 
Ghazali, A., Thiruchelvam, S., Sabri Muda, R., Nasharuddin Mustapha, K., Kadir, A. K., Norkhairi, F. F., Yahya, N., Hakimie, H., Isa, A. A. M., Mamat, A. F., Hasini, H., Sahari, K. S. M., Muda, Z. C. \& Jin, N. Y. (2018) “Development of Community-Based Early Warning System (CBEWS) in Enhancing Community Preparedness for Dam-Related Disaster in Malaysia". ASM Science Journal. 11 (2) p.117.

Hallegatte, S. (2012) "A Cost Effective Solution to Reduce Disaster Losses in Developing Countries: Hydro-Meteorological Services, Early Warning, and Evacuation". Policy Research Working Paper 6058. World Bank. Available at: https://openknowledge.world bank.org/bitstream/handle/10986/9359/WPS6058.pdf ?sequence=1\&isAllowed $=\mathbf{y}$

Henriksen, H. J., Roberts, M. J., van der Keur, P., Harjanne, A., Egilson, D. \& Alfonso, L. (2018) "Participatory Early Warning and Monitoring Systems: a nordic framework for webbased flood risk management". International Journal of Disaster Risk Reduction. 31, pp.1295-1306.

Hori, T. \& Shaw, R. (2012) Elements for a Sustainable Community Early Warning System in Cartago City, Costa Rica. In: Shaw, R. (Ed.) Community-Based Disaster Risk Reduction. Emerald Group.

IFRC (2012) "Community Early Warning Systems: Guiding Principles". International Federation of Red Cross Red Crescent Societies. Available at: https://www.ifrc.org/PageFiles/103323/1227800-IFRC-CEWS-Guiding-PrinciplesEN.pdf.

Junnaedhi, D. G., Riawan, E., Suwarman, R., Hadi, T. W., Lubis, A., Trilaksono, N. J., Rahayu, R., Kombara, P. Y., Waskito, R., Oktora, H. E., Supriatna, R., Anugrah, A., Maudzakkir, A. H. \& Setiawan, W. (2017) "Majalaya Flood Early Warning System: a community based approach". 2nd Transdisciplinary Research on Environmental Problems in Southeast Asia. IOP Conference Series: Earth and Environmental Science.

Kelman, I. \& Glantz, M. H. (2014) Early Warning Systems Defined. In: Zommers, Z. \& Singh, A. (Eds.) Reducing Disaster: Early Warning Systems for Climate Change. Dordrecht: Springer.

Khan, I., Razzaq, A., Jan, A., Riaz, S. \& Shehzad, N. (2018) An Analysis of Community Based Flood Early Warning System in the State of Azad Jammu and Kashmir. In: Amaratunga, D. \& Haigh, R. (Eds.) 7th International Conference on Building Resilience: Using Scientific Knowledge to Inform Policy and Practice in Disaster Risk Reduction. Bangkok, Thailand: Procedia Engineering.

Lanfranchi, V., Wrigley, S. N., Ireson, N., Ciravegna, F. \& Wehn, U. (2014) Citizen's Observatories for Situation Awareness in Flooding. In: Hiltz, S., Pfaff, M. S. \& Shih, P. C. (Eds.) 11th International ISCRAM Conference. University Park, Pennsylvania, USA.

Liu, Y., Yin, K., Chen, L., Wang, W. \& Liu, Y. (2016) “A Communiy-based Disaster Risk Reduction System in Wanzhou China". International Journal of Disaster Risk Reduction. 19, pp.379-389.

Marcherera, M. \& Chimbari, M. J. (2016) "A Review of Studies on Community Based Early Warning Systems". Jàmbá: Journal of Disaster Risk Studies. 8 (1) pp.206.

Marchezini, V., Horita, F. E. A., Matsuo, P. M., Trajber, R., Trejo-Rangel, M. A. \& Olivato, D. (2018) "A Review of Studies on Participatory Early Warning Systems (P-EWS):

Pathways to Support Citizen Science Initiatives". Frontiers in Earth Science. 6 (184). Marchezini, V., Trajber, R., Olivato, D., Aguilar Munoz, V., de Oliveira Pereira, F. \& Oliveira Luz, A. E. (2017) "Participatory Early Warning Systems: youth, citizen science and 
intergenerational dialogues on disaster risk reduction in Brazil". International Journal of Disaster Risk Science. 8 (4) pp.390-401.

Mulyasari, F. \& Shaw, R. (2013) "Role of women as risk communicators to enhance disaster resilience of Bandung, Indonesia". Natural Hazards. 69, pp.2137-2160.

Paripurno, E. T. \& Nugroho, A. R. B. (2018) The effectiveness of community-based early warning system of Kelud volcano eruption 2014. International Conference on Disaster Management 2018. MATEC Web of Conferences.

Parker, D. \& Handmer, J. (1998) "The Role of Unofficial Flood Warning Systems". Journal of Contingencies and Crisis Management. 6 (1) pp.45-60.

Perera, D., Agnihotri, J., Seidou, O. \& Djalante, R. (2020) "Identifying societal challenges in flood early warning systems". International Journal of Disaster Risk Reduction. 51 (101794).

Perera, D., Seidou, O., Agnihotri, J., Rasmy, M., Smakhtin, V., Coulibaly, P. \& Mehmood, H. (2019) Flood Early Warning Systems: A Review of Benefits, Challenges and Prospects. UNU-INWEH Report Series 08. Available at: https://inweh.unu.edu/wpcontent/uploads/2019/08/Flood-Early-Warning-Systems-A-Review-Of-BenefitsChallenges-And-Prospects.pdf.

Pineda, M. V. (2015) "Redefining Community Based Disaster Risk Management (CBDRM) through Enhanced Early Warning Processes". International Journal of Information and Education Technology. 5 (7).

Reed, M. S., Vella, S., Challies, E., de Vente, J., Frewer, L., Hohenwallner-Ries, D., Huber, T., Neumann, R. K., Oughton, E. A., Sidoli del Ceno, J. \& van Delden, H. (2018) “A Theory of Participation: What Makes Stakeholder and Public Engagement in Environmental Management Work?". Restoration Ecology. 26, pp.S7-S17.

Rowe, G. \& Frewer, L. (2000) "Public Participation Methods: A Framework for Evaluation". Science, Technology \& Human Values. 25 (1) pp.3-29.

Rowe, G. \& Frewer, L. (2005) "A Typology of Public Engagement Mechanisms". Science, Technology \& Human Values. 30 (2) pp.251-290.

Sari, A. D. \& Prayoga, N. (2018) Enhancing Citizen Engagement in the Face of Climate Change Risks: A Case Study of the Flood Early Warning System and Health Information System in Semarang City, Indonesia. In: Hughes, S., Chu, E. \& Mason, S. (Eds.) Climate Change in Cities: Innovations in Multi-Level Governance. Springer.

Smith, P. J., Brown, S. \& Dugar, S. (2017) "Community-based Early Warning Systems for Flood Risk Mitigation in Nepal". Natural Hazards and Earth System Sciences. 17, pp.423-437.

Stone, J., Barclay, J., Simmons, P., Loughlin, S. C., Ramon, P. \& Mothes, P. (2014) “Risk Reduction through Community-based Monitoring: The Vigias of Tungurahua, Ecuador". Journal of Applied Volcanology. 3 (11).

Sufri, S., Dwirahmadi, F., Phung, D. \& Rutherford, S. (2020) "A Systematic Review of Community Engagement (CE) in Disaster Early Warning Systems (EWSs)". Progress in Disaster Science. 5 (100058).

Tanwattana, P. (2018) "Systematizing Community-Based Disaster Risk Management (CBDRM): Case of Urban flood-prone community in Thailand upstream area". International Journal of Disaster Risk Reduction. 28, pp.798-812.

Thapa, P. S. \& Adhikari, B. R. (2019) "Development of community-based landslide early warning system in the earthquake-affected areas of Nepal Himalaya". Journal of Mountain Science. 16 (12) pp.2701-2713. 
UNDRR (2020) Terminology: Early Warning System [Online]. United Nations Office for Disaster Risk Reduction. Available at: https://www.undrr.org/terminology/earlywarning-system [Accessed 25 March 2020].

UNISDR (2006) Developing Early Warning Systems: A Checklist. Third International Conference on Early Warning. Available at: https://www.unisdr.org/files/608_10340.pdf.

United Nations (2006) Global Survey of Early Warning Systems: An assessment of capacities, gaps and opportunities towards building a comprehensive global early warning system for all natural hazards. United Nations. Available at: https://www.unisdr.org/2006/ppew/info-resources/ewc3/Global-Survey-of-EarlyWarning-Systems.pdf.

Valdivia, C., Seth, A., Gilles, J. L., Garcia, M., Jimenez, E., Cusicanqui, J., Navia, F. \& Yucra, E. (2010) "Adapting to Climate Change in Andean Ecosystems: Landscapes, Capitals, and Perceptions Shaping Rural Livelihood Strategies and Linking Knowledge Systems". Annals of the Association of American Geographers. 100 (4). 
Table II: Summary of findings from each case of participation in early warning, ordered by type of participant.

\begin{tabular}{|c|c|c|c|c|c|}
\hline Type of participant & Other actors and roles & Participatory activities & Location & Hazard & Source \\
\hline $\begin{array}{l}\text { Volunteers } \\
\text { (selected by researchers) }\end{array}$ & Researchers & $\begin{array}{ll}- & \text { Monitoring with rain gauges } \\
- & \text { Communicating via SMS }\end{array}$ & Philippines & Flood & Abon et al. (2012) \\
\hline Volunteers & $\begin{array}{l}\text { Researchers } \\
\text { (provided equipment and } \\
\text { training) }\end{array}$ & $\begin{array}{l}\text { - } \quad \text { Risk education programme } \\
\text { - } \quad \text { Monitoring via rain gauges } \\
\text { - } \quad \text { Evacuation drills }\end{array}$ & Sri Lanka & Landslide & $\begin{array}{l}\text { Baudoin et al. } \\
\text { (2016) }\end{array}$ \\
\hline Volunteers & $\begin{array}{l}\text { Municipal Civil Defence } \\
\text { Secretariat (established } \\
\text { network, provided training) }\end{array}$ & $\begin{array}{l}\text { - } \quad \text { Communication of in-situ information to } \\
\text { decision makers } \\
\text { - Dissemination of alerts within the community }\end{array}$ & Brazil & Flood & $\begin{array}{l}\text { da Cunha Luz } \\
\text { Barcellos et al. } \\
\text { (2017) }\end{array}$ \\
\hline Volunteers & $\begin{array}{l}\text { Met. service } \\
\text { (provided training to } \\
\text { volunteers) } \\
\text { Local government (identified } \\
\text { volunteers) }\end{array}$ & $\begin{array}{l}\text { - Take observations. Communicate } \\
\text { observations to operations centre, who } \\
\text { determine whether a warning is issued. }\end{array}$ & Philippines & Flood & $\begin{array}{l}\text { Espinueva and Nilo } \\
\text { (2011) }\end{array}$ \\
\hline Volunteers & Local government & $\begin{array}{l}\text { - Consultation meetings and involvement in } \\
\text { system design } \\
\text { - Take observations and communicate them to } \\
\text { central station } \\
\text { - Dissemination of warnings to community }\end{array}$ & Indonesia & $\begin{array}{l}\text { Debris } \\
\text { flow }\end{array}$ & $\begin{array}{l}\text { Fathani and } \\
\text { Legono (2012) }\end{array}$ \\
\hline Volunteers & $\begin{array}{l}\text { NGO; National Risk Prevention } \\
\text { and Emergency Management } \\
\text { Commission. } \\
\text { (established system, provided } \\
\text { training, organised } \\
\text { workshops, visit periodically) }\end{array}$ & $\begin{array}{l}\text { - } \begin{array}{l}\text { Monitoring via pluviometer } \\
\text { - }\end{array} \text { rommunicating warnings to nearby areas via } \\
\text { - Workshops to raise a wareness, development } \\
\text { of community contingency plan, evacuation } \\
\text { drills }\end{array}$ & Costa Rica & Flood & $\begin{array}{l}\text { Hori and Shaw } \\
\text { (2012) }\end{array}$ \\
\hline $\begin{array}{l}\text { Volunteers } \\
\text { (Elected residents) }\end{array}$ & County government & $\begin{array}{l}\text { - } \quad \text { Monitoring and surveying } \\
\text { - } \quad \text { Reporting of indicators to monitors } \\
\text { - } \quad \text { Communicating with governors via photos } \\
\text { - } \quad \text { Eent by smart phone } \\
\text { Education programme }\end{array}$ & China & Landslide & Liu et al. (2016) \\
\hline Volunteer network & $\begin{array}{l}\text { Scientists; civil defence } \\
\text { (provide training) }\end{array}$ & $\begin{array}{l}\text { - Observing conditions } \\
-\quad \text { Management of sirens and maintenance of } \\
\text { equipment }\end{array}$ & Ecuador & Volcanic & Stone et al. (2014) \\
\hline
\end{tabular}


Local disaster resilience

committee

Disaster Resilience LLC

(initiator)

\section{Committee}

(Working group; resident

sub-committee)

Local disaster management NGO; Dept. Hydrology and committee

\section{Community group}

(Women's Welfare

Associations)

Community disaster group

Water management and disaster management agencies (operation of automatic warning system)

Community group

University (assisted in development of riskmaps)

awareness raising

gramme)

utomatic monitoring
- Communicating observations to scientists and community

- Participatory mapping

- Committee run social media site for sharing of Hawaii

Multiple

Baudoin et al. knowledge

- Knowledge sharing via elders

- Participation in design of system via multiagency working group

- Sharing of information with wider community

- Mapping of historical flood events

- Monitoring and recording flood levels

- Maintenance of equipment

- Dissemination of warnings via sirens, megaphone, mobile device

- Sharing local knowledge with others

- Manual monitoring of rainfall and water levels

- Assessment of automatic warnings with local knowledge

- Dissemination of warnings via walkie talkie, SMS and instant messenger

- Sharing risk knowl edge

- Disseminating warnings via social network

- Provision of communication link between authorities and community

- Communicating and confirming alerts via walkie talkie

Australia

Nepal

Flood

Gautam and

Phaiju (2013)

Disseminating warnings to community

- Training simulations and awareness raising activities

- Monitoring using staff gauges, operated and managed by community

- Development of community disaster plan

- Collaboration with university to produce flood riskmaps

\section{Indonesia Flood Junnaedhi et al.}

Indonesia

Flood $\quad \begin{aligned} & \text { Mulyasari and } \\ & \text { Shaw (2013) }\end{aligned}$

Indonesia

Flood

Sari and Prayoga

Thailand

Flood

Tanwattana

(2018) 


\begin{tabular}{|c|c|c|c|c|c|c|}
\hline $\begin{array}{l}\text { Demographic group } \\
\text { (Female heads of } \\
\text { household) }\end{array}$ & $\begin{array}{l}\text { Local government; NGO; } \\
\text { private companies; } \\
\text { researchers } \\
\text { (funding, technical and } \\
\text { development expertise; } \\
\text { training) }\end{array}$ & - & $\begin{array}{l}\text { Checking and reporting issues with landslide } \\
\text { prevention infrastructure } \\
\text { Communicating landslide risk to community + } \\
\text { providing outreach }\end{array}$ & Colombia & Landside & $\begin{array}{l}\text { Coles and } \\
\text { Quintero-Angel } \\
\text { (2018) }\end{array}$ \\
\hline $\begin{array}{l}\text { At-risk community; } \\
\text { demographic group (school } \\
\text { students) }\end{array}$ & $\begin{array}{l}\text { Researchers; National Early } \\
\text { Warning and Monitoring } \\
\text { Centre (implemented } \\
\text { programme) }\end{array}$ & $\begin{array}{l}- \\
-\end{array}$ & $\begin{array}{l}\text { Knowledge sharing workshops, including } \\
\text { participatory social cartography and } \\
\text { intergenerational learning activities } \\
\text { 'Protection map game' (contingency plan } \\
\text { design) }\end{array}$ & Brazil & Flood & $\begin{array}{l}\text { Marchezini et al. } \\
\text { (2017) }\end{array}$ \\
\hline $\begin{array}{l}\text { At-risk community; } \\
\text { Volunteer }\end{array}$ & $\begin{array}{l}\text { Researchers; local } \\
\text { government (development of } \\
\text { system) }\end{array}$ & $\begin{array}{l}- \\
-\end{array}$ & $\begin{array}{l}\text { Provision of local knowledge to inform system } \\
\text { design } \\
\text { Assigned person receives warning }\end{array}$ & Nepal & Landslide & $\begin{array}{l}\text { Thapa and } \\
\text { Adhikari (2019) }\end{array}$ \\
\hline $\begin{array}{l}\text { At-risk community; } \\
\text { selected volunteers }\end{array}$ & $\begin{array}{l}\text { Res earchers (conducted } \\
\text { workshops) }\end{array}$ & $\begin{array}{l}- \\
- \\
-\end{array}$ & $\begin{array}{l}\text { Workshops and development of hazard maps } \\
\text { Interviewing community el ders for risk } \\
\text { knowledge } \\
\text { Making own forecasts based on indicators }\end{array}$ & Bolivia & $\begin{array}{l}\text { Climate } \\
\text { related }\end{array}$ & $\begin{array}{l}\text { Valdivia et al. } \\
\text { (2010) }\end{array}$ \\
\hline $\begin{array}{l}\text { At-risk community; } \\
\text { committee }\end{array}$ & Local council; researchers & - & $\begin{array}{l}\text { Participatory risk ass essment } \\
\text { Monitoring and communicating observations } \\
\text { to officials }\end{array}$ & Philippines & Landslide & $\begin{array}{l}\text { Gumiran et al. } \\
\text { (2019) }\end{array}$ \\
\hline $\begin{array}{l}\text { At-risk community; } \\
\text { Community disaster group } \\
\text { and alert team }\end{array}$ & $\begin{array}{l}\text { Community organisation; } \\
\text { university; NGO (organised } \\
\text { workshops and training, } \\
\text { engaged existing community } \\
\text { group) }\end{array}$ & $\begin{array}{l}- \\
- \\
- \\
- \\
-\end{array}$ & $\begin{array}{l}\text { Workshops with government repres entatives } \\
\text { Knowledge sharing with other community } \\
\text { groups } \\
\text { Risk mapping } \\
\text { Community group disseminate warnings via } \\
\text { radio } \\
\text { Simulations and development of SOPs for } \\
\text { preparedness }\end{array}$ & Indonesia & Volcanic & $\begin{array}{l}\text { Paripurno and } \\
\text { Nugroho (2018) }\end{array}$ \\
\hline At-risk communities & Officials & $\begin{array}{l}- \\
- \\
-\end{array}$ & $\begin{array}{l}\text { Monitoring using local indicators } \\
\text { Triangulation of official warnings and } \\
\text { observations } \\
\text { Dissemination of warnings via shouting }\end{array}$ & India & Flood & $\begin{array}{l}\text { Acharya and } \\
\text { Prakash (2019) }\end{array}$ \\
\hline At risk communities & $\begin{array}{l}\text { Researchers (initiated system; } \\
\text { established automatic and }\end{array}$ & - & $\begin{array}{l}\text { Social cartography } \\
\text { Monitoring via rain and stream gauges }\end{array}$ & Colombia & $\begin{array}{l}\text { Flood; } \\
\text { landslide }\end{array}$ & Arias et al. (2016) \\
\hline
\end{tabular}


manual monitoring network;

$$
\text { training) }
$$

At-risk community

Local government and various local organisations

At-risk communities

Res earchers (conducted study

to identify communities preferred design)

NGO; local government

(initiator, training);

researchers (developed

additional modelling tool)

$\begin{array}{ll}\text { General public } & \text { Met service } \\ \text { General public } & \begin{array}{l}\text { Researchers (established } \\ \text { system) }\end{array}\end{array}$

\section{General public}

Researcher (developed system prototype)

(recommendations made only)
- Participatory hazard, vul nerability and

capacity assessment.

- Evacuation drill and awa reness campaigns

- Participation in design of system

- Participatory mapping

- Monitoring via gauges

- Disseminating warnings to communities and authorities

- Participatory evacuation planning and mock drills

- Contributing geo-tagged photos to online portal for monitoring and real time updates

- Report threats to authorities via uploading images to web application

- Participation in discussions about local a rea on the app.

- Provision of observations on request

- Observing and reporting of incidents on a web app for real-time monitoring

- Participatory rural appraisal

- Community groups share information and raise awareness

- Crowd sourcing of observations

\begin{tabular}{|c|c|c|}
\hline Malaysia & $\begin{array}{l}\text { Flood } \\
\text { (Dam } \\
\text { failure) }\end{array}$ & $\begin{array}{l}\text { Ghazali et al. } \\
\text { (2018) }\end{array}$ \\
\hline Pakistan & Flood & Khan et al. (2018) \\
\hline Nepal & Flood & Smith et al. (2017) \\
\hline Iceland & Flood & $\begin{array}{l}\text { Henriksen et al. } \\
\text { (2018) }\end{array}$ \\
\hline $\begin{array}{l}\text { United } \\
\text { Kingdom; } \\
\text { Netherland } \\
\text { s; Italy }\end{array}$ & Flood & $\begin{array}{l}\text { Lanfranchi et al. } \\
\text { (2014) }\end{array}$ \\
\hline Philippines & Flood; fire & Pineda (2015) \\
\hline Kenya & Multiple & $\begin{array}{l}\text { Senaratna et al. } \\
\text { (2014) }\end{array}$ \\
\hline
\end{tabular}

